\title{
The causes of stage expansion of WTI/Brent spread
}

\author{
Hong-Zhi $\operatorname{Tian}^{1} \cdot$ Wei-Di Lai ${ }^{1}$
}

Received: 4 May 2019 / Published online: 10 October 2019

(c) The Author(s) 2019

\begin{abstract}
Historically, the price of WTI crude oil futures has long been higher than that of Brent by $\$ 2 / \mathrm{barrel}$, but the spread between 2011 and 2015 was reversed and expanded to \$24/barrel. In order to analyze the difference between two crude oil price variables with the same trend and phase separation using one method of analysis, this paper constructs a dynamic comparative analysis framework using the method of time-point decomposition of fluctuation factors to determine the different reasons and amplitudes for monthly fluctuations in the two price systems in the sample interval. The study found that the sensitive response of Brent futures price indicators to the world's crude oil supply resulting from the depletion of oil in the North Sea oil field prompted it to rise in 2011-2015. For the WTI price system, due to the increase in the US shale oil production after 2008 and the restrictions in domestic pipeline transportation capacity, the increase in the Cushing crude oil inventory caused downward pressure on the WTI price. With the lifting of the US crude oil export ban in December 2015, arbitrage space disappeared, and the spread between the two gradually narrowed.
\end{abstract}

Keywords WTI $\cdot$ Brent $\cdot$ Cushing crude oil inventory $\cdot$ North Sea oil field $\cdot$ Shale oil

\section{Introduction}

The US West Texas Intermediate (WTI) crude oil futures prices and British Brent crude oil futures prices are often used as important reference indicators for world crude oil futures trading. For a long time, there have only been small spread of about $\$ 2 /$ barrel, and the dynamic evolution trend is basically the same. However, the spread between WTI and Brent crude oil futures in the period between 2011 and 2015 reached more than 20 dollars, an abnormal phenomenon in the world crude oil market. Analyzing the volatility difference between two crude oil price variables with the same trend and phased separation using the same analytical model not only challenges traditional econometric methods, but also makes it difficult to study the evolution of world crude oil price dynamics. Based on this, this paper constructs a multi-model dynamic comparative analysis framework by using the time-point decomposition method of fluctuating

Edited by Xiu-Qin Zhu

Hong-Zhi Tian

nwuthz@nwu.edu.cn

1 School of Economics and Management, Northwest

University, Xi' an 710127, Shaanxi, China factors and determines the causes of the fluctuations of the two types of price systems and the extent of their impact for each month during the period 2011-2015. It then analyzes the influence of factors hidden behind the expansion of the spread - the depletion of North Sea crude oil, the US shale oil revolution, and the lifting of the crude oil export ban-in the world crude oil supply and futures trading levels. At present, China is in the process of industrialization and urbanization, with huge demand for crude oil, making China the world's largest importer of crude oil and the second largest consumer. This paper studies the dynamic characteristics of WTI and Brent oil price index fluctuations, reveals its inherent laws, helps to accurately understand the price trend of the international crude oil market, ensures the safety of China's crude oil demand, and provides suggestions for the development of the Shanghai crude oil futures market, which is initially established in China.

Although it has been more than 40 years since the first oil crisis in 1973, the continuous volatility of crude oil prices has caused problems for the development of the world economy. In order to avoid the economic hazards of international crude oil spot price fluctuations, the New York Mercantile Exchange and the London Intercontinental Exchange launched crude oil futures contracts in 1983 and 1988, respectively (Shi et al. 2018). These two exchanges 
are now representative of the world crude oil futures market with a strong market environment, diverse market trading entities, and active market transactions. Since then, the crude oil futures market has begun to become the place to publish world's crude oil price. Crude oil futures prices have become an important and uncertain variable factor in the development of the world economy, and their fluctuations have received much attention. Wang and Wang (2018) show that there are nonlinear effects of international oil prices, the US economic uncertainty and volatility spillover of China's stock price to other variables. Traditional finance theory holds that the futures price of a commodity is mainly affected by the supply and demand of the commodity and is also affected by monetary policy, economic cycles, and especially speculative factors (Sui and Guo 2014). In view of the close correlation between crude oil and the world economy, the US dollar exchange rate, geopolitics, and other factors, there has been a lot of empirical research on the formation and fluctuation of its futures prices. This paper traces the sources and sorts out the literature on the temporal and spatial characteristics of commodity prices, the evolution of the world crude oil market, and the reasons for the phased separation of Brent and WTI futures price indicators.

With regard to the temporal and spatial characteristics of general commodity prices, in addition to the traditional theory of supply and demand balance, the early literature has conducted in-depth research on the changes in commodity prices in terms of time and space. For example, Working (1949), Brennan (1958), and Wright and Williams (1982) believe that the storage of goods has an important impact on intertemporal prices for commodities. Makki et al. (1996) used American wheat as an example and found that price was not limited only to storage factors but also that commodity trade had an important impact. Further, Miranda and Glauber (1995) found that in the absence of long-term supply and demand imbalances between the two regions, trade and storage have similar market effects, driven by stochastic output; in the case of long-term imbalances between supply and demand, trade will significantly affect storage activities, but storage has little impact on trade. Scheitrum et al. (2018) also found that Brent and WTI crude oil futures have two important differences: First, the delivery methods of the two are very different. Thanks to the superior geographical position of North Sea oil field and the coherent Eurasia, Brent crude oil can be easily transported all over the world, so its spot price is more related to the port and coastal crude oil grade. The WTI system can better reflect the specific supply and demand fundamentals and infrastructure in the USA. Second, the crude oil reserve capacity of the two is very different. WTI's floor reserves are 73 million barrels, while Brent crude has only 8.4 million barrels of available reserves. ${ }^{1}$ The theory is that significantly different storage facilities may create a gap between intertemporal price of one market and another.

Regarding the cognition and evolution of the world crude oil market, Adelman (1984) believes that the world crude oil market is a huge oil storage pool like the world's oceans. By means of transfers, crude oil should flow to the most scarce and highest-priced areas. Although Weiner (1991) denied Adelman's hypothesis, he believes that if the quality of crude oil is similar, its price fluctuations should change synergistically. Fattouh (2010) used the TAR model to find that even for different varieties of crude oil, the price is still closely related, and the spread is stable, but the dynamic adjustment process of international crude oil prices is different. This means that the crude oil market in this reservoir is not necessarily integrated at every stage of time. Further, Kolodziej and Kaufmann (2013) studied the long-term and short-term relationships between WTI crude oil prices, trader positions, interest rates, and crude oil inventories through an estimated vector autoregressive model and found that both trading positions and crude oil inventories play a role in price discovery. Also, that there is a two-way causal relationship between crude oil futures prices and trading positions, that is, speculation may affect the formation mechanism of crude oil prices. Research by Ghoshray and Trifonova (2014) shows that the world crude oil market has been highly integrated, and the prices of all varieties of crude oil are cointegrated. Further, Ji and Fan (2016) used graph theory to study the evolution of the world crude oil market and confirmed that the world crude oil market has been integrated. They also found that the links between South America and North America and Africa are relatively stable. The crude oil markets of the USA, Angola, and Saudi Arabia are at the core, while the crude oil markets of East and Southeast Asian countries are marginal.

Kilian (2007) shown that policies aimed at dealing with higher oil prices must take careful account of the origins of higher oil prices. Alquist and Kilian (2010) found that increased uncertainty also causes precautionary demand for oil to increase, resulting in an immediate increase in the real spot price. Kilian and Murphy (2014) found that speculative demand shifts played an important role during earlier oil price shock episodes including 1979, 1986, and 1990. Alquist and Guénette (2014) showed that even in the best-case scenario, the increase in the US oil production is unlikely to have a large effect on the global oil market's demand-supply balance, so its effect on the price of oil is expected to be limited. Furthermore, the USA enjoys unique infrastructural and technological advantages that make it

\footnotetext{
$\overline{1}$ Data source: Energy Information Administration (EIA).
} 
unlikely that rapid increases in unconventional production can be achieved elsewhere.

Kao and Wan (2012) show the ability of WTI in reflecting market conditions decreases sharply, and WTI's efficiency in processing information has been surpassed by Brent's since the second half of 2004. In the short run, the WTI distortion is related to its price discount problem, but the distortion cannot be indicated by contangos. Yu et al. (2018) show that there is strong relationship between American stock price and oil price. In the long run, WTI's price discount problem coexists with a positive forward curve and both have harmed the price discovery role of WTI. The rising inventories in Cushing significantly deteriorate WTI's ability in serving as a world benchmark. Liu et al. (2015) used one-second and one-minute high-frequency data to better describe the dynamic changes in international oil prices and found that the intercontinental exchange crude oil futures contract is the most important source of Brent futures price discovery. It was also found that the supply of crude oil in the Cushing region of the USA weakened the cointegrated relationship between Brent and WTI prices. Chu and Xu (2011) used the world's major crude oil futures prices to conduct cointegration tests with WTI and Brent indicators, respectively, and found that WTI has lost its relationship with oil prices in most regions, losing the function of world benchmark, and its price is undervalued and Brent crude oil futures prices are more representative of the international oil price benchmark. However, Kilian (2016) pointed out that due to the decline in production in the North Sea oil field, the liquidity of the London Intercontinental Exchange is insufficient. Whether the reserves support the Brent crude oil system in the long term as a world oil price index is a realistic problem in the world crude oil market.

Now, we discuss the reason for the phased separation of WTI and Brent futures price indicators from 2011 to 2015. Heidorn et al. (2015) found that the exposure of financials is the key driver of the Brent-WTI spread. Büksahin et al. (2013) found that during 2011-2012, Brent oil prices only opened a distance from WTI oil prices and did not open distance from other oil price indicators, or the actual situation is that WTI oil prices are lower than other oil price indicators. Between 2004 and 2012, due to factors such as the world economic cycle and the US infrastructure bottleneck, problems with the transportation and storage of the US crude oil have limited the exploitation and refining of the non-US crude oil, resulting in the spread of WTI and Brent indicators. The article also highlights the importance of Cushing's crude oil storage capacity for WTI futures prices as the actual delivery location for crude oil futures on the New York Mercantile Exchange. At the futures market level, after controlling for variables such as macroeconomics and physical markets, some studies have found that the daily data of the total long position of commodity index traders on the New York Mercantile Exchange help to predict the spread between WTI and Brent. In addition, Scheitrum et al. (2018) studied the arbitrage mechanism of the Intercontinental Exchange and the New York Mercantile Exchange crude oil futures and analyzed the problem through the structural mutation of the Brent and WTI futures price curves, which better fit the dynamic process of the two.

Using the latest CUSUM detection method with no prespecified structural mutation points, Chen et al. (2015) found that the WTI and Brent spread sequence had a structural mutation in December 2010, moving from a stationary sequence to a non-stationary sequence. From December 1993 to April 2016, Ye and Karali (2016) used the Bai-Perron test, which allows the date of the mutation to be unknown, to estimate the structural mutation of the oil price sequence. It was also found that the WTI and Brent crude oil futures price series produced two structural mutations in February 2005 and December 2010 and confirmed that the price of Brent and WTI was cointegrated before and after the first interruption in February 2005, and the two have a robust dynamic change correlation. However, after the second structural change in December 2010 and before April 2016, the two no longer have the characteristics of cointegration. The article further adopts the relative price substitution method of Carter and Smith (2007), and it is estimated that the structural mutation in December 2010 has a much higher impact on the two futures prices than in February 2005. These results indicate that structural mutations in 2010 have a greater impact on crude oil prices than earlier mutations. Liu et al. (2018), through unit root and cointegration tests, once again confirmed that there was a structural mutation in the WTI and Brent oil price spread sequence in December 2010, from a stationary time series to a non-stationary time series, and the spread was mainly affected by the impact of the US crude oil production.

Because international oil prices are priced in the US dollars (USD), the change of the USD exchange rate is also one of the hot issues in empirical analysis. Aloui et al. (2013) found that the rise in WTI and Brent is associated with the depreciation of the dollar. Han et al. (2017) found that the USD index is the most important factor for WTI and suggested that close attention should be paid to the USD index for predicting the trend of global oil prices. Yang et al. (2017) employed the wavelet coherence framework and found that the crude oil price has a negative relationship with exchange rates for oil-exporting countries. Živkov et al. (2019) investigate the interrelationship between the Brent oil price and the exchange rate in ten emerging markets of Eastern Europe, Asia, Africa, and South America. The wavelet coherence results suggest that strong coherence is present during world financial crises in the oil-exporting countries and in the majority of the oil-importing countries. In the latest research results, Bedoui et al. (2019) showed that 


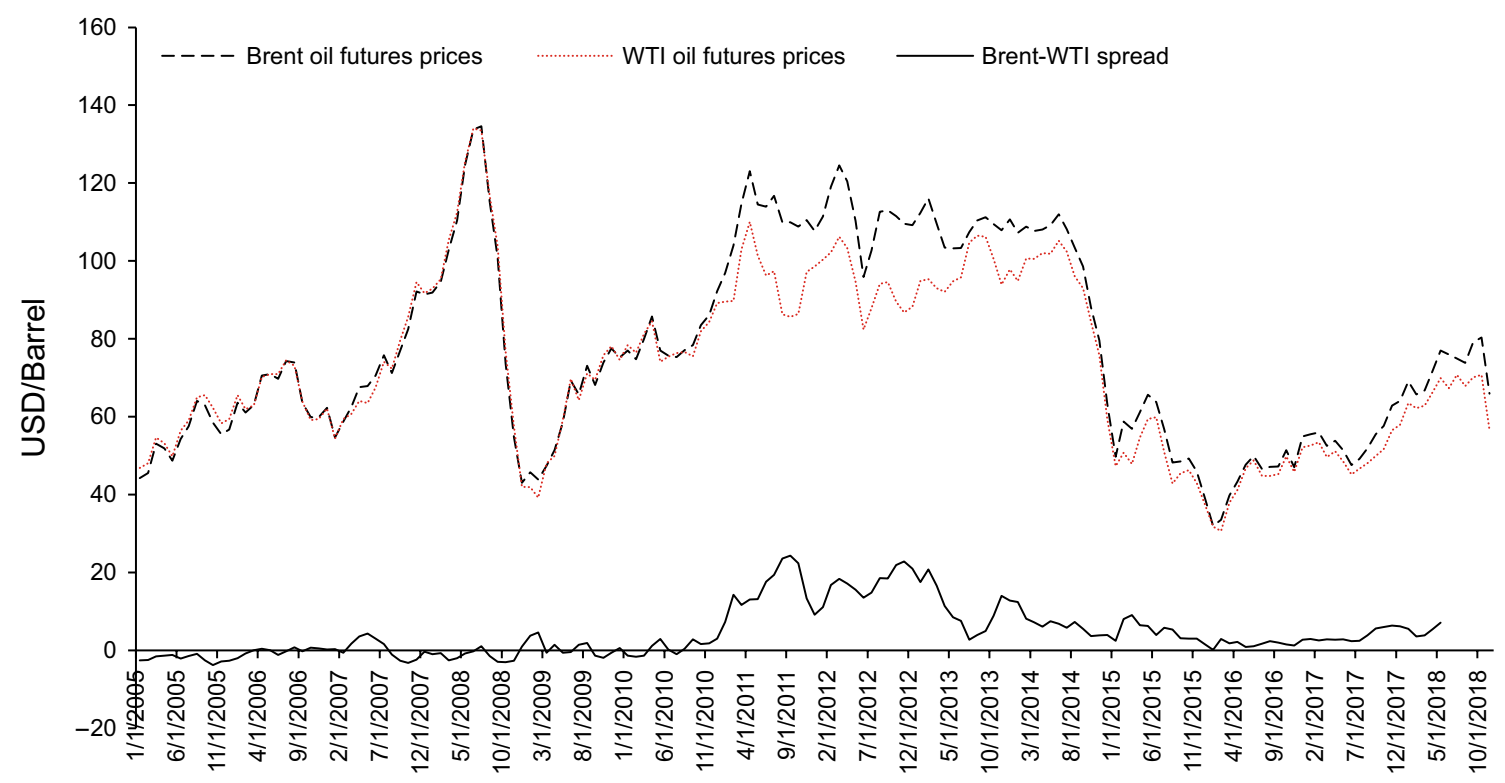

Fig. 1 Brent and WTI futures price timing chart. Source: CEIC Database

energy commodities and precious metals differ from other trading products. In fact, both oil and gold prices are leading economic variables that drive the evolution of the world economy. During crisis periods, the dependence between oil, gold, and the USD is stronger compared with the dependence during untroubled periods. Moreover, the co-movement is accelerated, which is explained by the unusual movement of the USD during the global financial crisis of 2007-2009.

In summary, the preliminary research not only carried out in-depth analyses on commodity futures prices and the international crude oil market, but also found that the spread sequence of the Brent and WTI oil price index system occurred as non-stationary mutations around December 2010. At the same time, the synergistic relationship between Brent and WTI oil prices has also undergone profound changes. The existing literature focuses on the judgment of the evolution of the two, lacks the analysis of the reasons for the evolution, and does not explain the expansion of the spread between the two crude oil markets, and most of the current empirical analysis frameworks cannot explain the root cause of the spread returning to their pre-2011 status after 2015. In order to explain the problem more accurately, first, we inherit the idea of the time-point decomposition of variable fluctuation factor in Tian (2015), overcome the disadvantage that impulse response functions can only give one conclusion for the whole sample interval, and realize the microscopic observation of variable change at the time point. Second, the contribution of this paper is to construct multivariate models, providing a dynamic analysis framework for comparable sensitivity responses, making the analysis of the spread between Brent and WTI crude oil futures prices time specific and providing strong evidence and realizing a small development of empirical analysis.

\section{Typical facts and timing characteristics of the world crude oil futures market}

The spreads between crude oils of similar quality should have only three components: the difference in quality produced by different oil fields, the difference in shipping distance, and the discounted delivery time. Both Brent and WTI's underlying in oil futures market are light and lowsulfur crude oil, and the quality of oil is similar. Due to the transportation distance and delivery time, WTI oil prices have historically been higher than Brent's by $\$ 2$ per barrel, and this feature should remain basically unchanged for the reasons outlined above. However, as shown in Fig. 1, since 2011, Brent oil prices have begun to surpass WTI oil prices, and during the period from 2011 to 2015 , the two price systems have had a spread of up to $\$ 24 / \mathrm{barrel}$, and although the spread has narrowed it has not fully recovered to the state before 2011. In addition, Fig. 1 shows that the basic feature of the separation of the two trends from 2011 to 2015 is that the WTI oil price has dropped significantly, while the Brent oil price has shown a gentle time trend.

In order to analyze the reason for the reversal of the spread and its expansion, and assuming that the world crude oil market structure began to change fundamentally in 2011, it should be safe to assume that the spread between the two should continue to grow, but, after 2015, it can be seen that the small spreads of the earlier time resumed. These short 


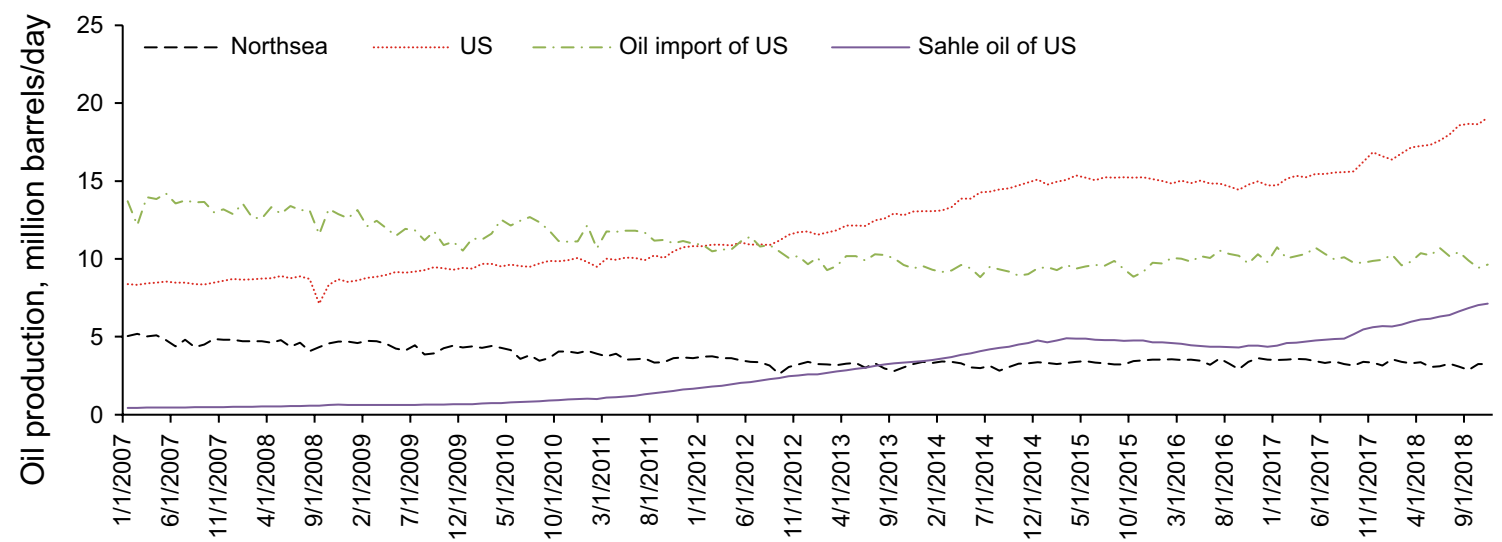

Fig. 2 North Sea oil field, US shale oil, US imports, and US crude oil production. Source: EIA (U.S. Energy Information Administration) database

and large deviations are confusing to the academic world; therefore, under the premise that the world crude oil market has not undergone fundamental changes, and in order to capture the dynamic changes in the world crude oil market, the fundamentals of market supply and demand are used to provide an intuitive understanding. Figure 2 provides a time series analysis of the North Sea oil field production supporting the Brent futures price system and the US shale oil and US crude oil production supporting the WTI futures price system.

First, the North Sea oil field has been developing on a large scale since 1959 and has been an important source of crude oil for European countries in the long run. However, as Fig. 2 shows, crude oil production in the North Sea oil field has declined significantly in recent years and was overtaken by the US shale oil production in January 2014. This paper estimates that in November 2018, the crude oil output of the North Sea oil field only accounted for $3.26 \%$ of the world's total crude oil production, equaling $16.99 \%$ of the US production. The direct consequences of the depletion of the North Sea oil field are: the loss of self-sufficiency in European crude oil; Britain as a traditional crude oil-exporting country became a net importer of crude oil in 2005; the crude oil trade in European countries is more closely related to the world market. With its convenient shipping conditions, the crude oil produced in the North Sea oil field is mostly traded in real time and there is no huge oil storage facility. Therefore, in the short term, the decline in output of the North Sea oil field often brings the illusion of an insufficient supply of crude oil to the traders of the London Intercontinental Exchange, which puts upward pressure on the local futures price. In the long run, the decline in the world share of the North Sea oil field means that its influence is reduced, and its production capacity cannot be used to significantly change the world crude oil supply pattern. In the end, the representative position of the London
Intercontinental Exchange in the world crude oil futures market may be shaken.

Second, stimulated by the booming world economy and high international oil prices before 2008, the rapid development of hydraulic fracturing and horizontal drilling technology has promoted the exploitation and production of the US domestic shale oil. Figure 2 shows that the US shale oil production began to increase rapidly in 2010, and the growth continued until 2015. As the international oil price in 2016 was lower than the mining cost of shale oil, the shale oil mining industry production temporarily reversed, but with a series of optimization measures and with the rebound in international oil prices in 2017, the US shale oil production has returned to steady growth since 2017 . By November 2018, its output reached 7.13 million barrels/day, which was higher than that of the North Sea oil field, and it has become an important part of the US crude oil consumption. The mass production of the US shale oil prompted the country to lift the 40-year crude oil export ban in 2015 .

Third, Fig. 2 shows that although the total domestic crude oil production of the USA continues to increase, crude oil imports have consistently exceeded their domestic shale oil production, and the absolute amount of imported oil is still huge. This has left the USA with a low oil price preference and has not enabled the country to form an effective international supply of crude oil. The reason is that, first of all, Cushing Town is located in the central and western regions of the USA and is an important crude oil transportation hub. ${ }^{2}$ However, the region is constrained by the capacity of oil pipelines and railway transportation, so that crude oil is often not transported to US coastal terminals quickly and

\footnotetext{
2 The US crude oil market is divided into five regions, known as the Petroleum Administration for Defense Districts (PADDs). Cushing is located in Oklahoma and belongs to PADD 2.
} 
is not effectively supplied to domestic refineries. Therefore, the USA needs to import crude oil. Second, although the transport capacity situation has improved after 2012, the US crude oil export ban restricted the physical delivery of crude oil futures trading. Even if the transaction is successful, the oil cannot be transported abroad, and therefore, there is no supply-level impact on the international crude oil market. This situation continued until the lifting of the ban at the end of 2015. Finally, because most refineries in the USA were built decades ago and can only accept light mixed oil from the Permian Basin, their refinery equipment has relatively high requirements for oil, so a certain amount of overseas heavy oil is still needed. Therefore, multiple factors have made it difficult for the US crude oil supply to achieve self-sufficiency.

\section{Analysis framework design and measurement model construction}

\subsection{Analysis framework design}

Although both WTI and Brent are widely recognized as world oil price indicators, they are limited by the geographical location of their own futures markets, institutional arrangements, and other factors and may have different sensitivity responses to different oil price fluctuation factors. The oil price is sensitive to these fluctuation factors, and the oil price is the most direct representative of these factors. Combined with the previous analysis, we construct four three-variable structural vector autoregressive (SVAR) models for dynamic comparative analysis from three dimensions of crude oil supply, demand, and price, and six refined indicators: world crude oil production, North Sea oil field crude oil production, Cushing crude oil inventory, world crude oil demand, Brent crude oil futures prices, and WTI crude oil futures prices.

The dynamic comparative analysis framework is as follows: First, according to the basic viewpoint that WTI and Brent crude oil futures prices are representative indicators of the current world crude oil futures market, Model 1 and Model 2 are developed. The characteristics of these two models are that the fluctuations of WTI and Brent crude oil futures prices are measured under the same supply and demand conditions, which is the basic model of this paper. Second, because the London Brent oil price was born out of the influence of the North Sea oil field, this paper uses Model 3 to investigate whether the Brent oil price has significantly increased in the past few years when the North Sea oil field has been depleted. Finally, the purpose of this paper is to examine the differences in fluctuations in futures oil price indicators. Therefore, in order to reflect the new changes in the US shale oil production in recent years,
Table 1 Dynamic comparative analysis framework

\begin{tabular}{lllll}
\hline Variable & Model 1 & Model 2 & Model 3 & Model 4 \\
\hline worldsup $_{t}$ & $\sqrt{ }$ & $\sqrt{ }$ & & \\
northseasup $_{t}$ & & & $\sqrt{ }$ & \\
cushingst $_{t}$ & & $\sqrt{ }$ & $\sqrt{ }$ & $\sqrt{ }$ \\
oildm $_{t}$ & $\sqrt{ }$ & $\sqrt{ }$ & $\sqrt{ }$ & \\
brentfutpr $_{t}$ & $\sqrt{ }$ & $\sqrt{ }$ & & $\sqrt{ }$ \\
wtifutpr $_{t}$ & & $\sqrt{ }$ & & \\
\hline
\end{tabular}

In order to facilitate the comparison of the measurement results, this paper has unified the size of each model impulse

Model 4 is an in-depth study of the impact of the Cushing crude oil inventory on the WTI indicator system. At the same time, the results of Model 1 and Model 4 were compared to find out the real reason why the WTI indicator was lower after 2011. Through multi-model comparison and analysis, we can find the fluctuation characteristics of international oil price indicators, as shown in Table 1.

In Table 1, worldsup $_{t}$ represents the world crude oil sup-

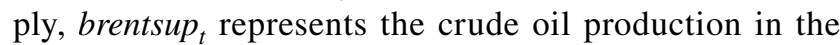
North Sea oil field, cushingst $_{t}$ represents the Cushing crude oil inventories, oildm ${ }_{t}$ represents the world crude oil demand, brentfutpr $_{t}$ represents the Brent crude oil futures price, and wtifutpr $_{t}$ represents the WTI crude oil futures price. The comparable physical basis for the two price systems is that both WTI and Brent crude oils are light, low-sulfur crude oils.

\subsection{Construction of the measurement model}

The econometric method benefits from the statistics of economic data, and the sample capacity often becomes a key factor in successful modeling under the dual goal of weighing the accuracy of parameter estimation and sufficient degrees of freedom. Although the parameter estimation technique of the econometric model benefits from an increased sample size to obtain better estimation accuracy and robustness, the traditional econometric model can only measure a single conclusion utilizing such a large sample thereby wasting some of the sample information.SVAR model is often used to measure the response of a variable in an economic system after a shock, such as Redl (2015), and it can also construct of forecast scenarios conditional on hypothetical sequences of future structural shocks in Baumeister and Kilian (2014), but the larger the sample capacity, the easier the impulse response function will smooth out the fluctuations in the local interval after combining the shock effects of each period. However, the time factor decomposition method for the fluctuating factor can make up for this defect (Tian 2015). Combined with the specific research purpose, $Y_{t}$ is assumed to be a three-variable column vector: $y_{1}, y_{2}, y_{3}$, 
respectively, representing the three variables in each model in Table 1. The standard form of the SVAR model is as follows:

$D_{0} Y_{t}=E+D_{1} Y_{t-1}+D_{2} Y_{t}+\cdots+D_{s} Y_{t-s}+u_{t}$

where $D_{0}$ represents a non-singular structural matrix, the form is shown in Eq. (2), and its main diagonal element represents the immediate feedback effect of each economic variable on itself, rather than the main diagonal element. Taking $d_{12}$ as an example, it represents the magnitude of the immediate effect of $y_{2 t}$ on $y_{1 t}$. It can be seen that the biggest improvement in the SVAR model over the VAR model is that the important current correlation between variables is reflected, rather than hidden in the error term.

$D_{0}=\left(\begin{array}{lll}d_{11} & d_{12} & d_{13} \\ d_{21} & d_{22} & d_{23} \\ d_{31} & d_{32} & d_{33}\end{array}\right)$

In Eq. (1), $E$ denotes the intercept column vector, $s$ represents the lag order, and $u_{t}$ is the supply shock, the demand shock, and the speculative arbitrage shock, respectively, represented by $u_{1 t}, u_{2 t}, u_{3 t}$, the variance covariance matrix is $\Sigma_{u}$, and the matrix form is Eq. (3). If the three structural perturbation vectors are independent of each other, then Eq. (3) becomes a diagonal matrix.

$\Sigma_{u}=\left(\begin{array}{ccc}\operatorname{var}\left(u_{1 t}\right) & \operatorname{cov}\left(u_{1 t}, u_{2 t}\right) & \operatorname{cov}\left(u_{1 t}, u_{3 t}\right) \\ \operatorname{cov}\left(u_{2 t}, u_{1 t}\right) & \operatorname{var}\left(u_{2 t}\right) & \operatorname{cov}\left(u_{2 t}, u_{3 t}\right) \\ \operatorname{cov}\left(u_{3 t}, u_{1 t}\right) & \operatorname{cov}\left(u_{3 t}, u_{2 t}\right) & \operatorname{var}\left(u_{3 t}\right)\end{array}\right)$

Further variants of Eq. (1) can be converted into a simplified form:

$Y_{t}=B+A_{1} Y_{t-1}+A_{2} Y_{t-2}+\cdots+A_{s} Y_{t-s}+\varepsilon_{t}$

where $B=D_{0}^{-1} E, A_{i}=D_{0}^{-1} D_{i}$, and $\varepsilon_{t}=D_{0}^{-1} u_{t}$. Move the lag terms on the right side of Eq. (4) to the left of the equation:

$A(L) Y_{t}=B+\varepsilon_{t}$

$A(L)=I_{3}-\sum_{i=1}^{s} A_{i} L^{i}, I_{3}$ is a third-order identity matrix. By multiplying both ends of Eq. (5) by $A(L)^{-1}$ at the same time, we can get the form of the infinite order vector moving average model:

$Y_{t}=A(L)^{-1} B+A(L)^{-1} \varepsilon_{t}$

If we are concerned about the effect of each pulse on $y_{3, t}$, we can use the following partial derivative function:

$\theta_{31}^{(s)}=\frac{\partial Y_{3, t+s}}{\partial u_{1, t}}, \theta_{32}^{(s)}=\frac{\partial Y_{3, t+s}}{\partial u_{2, t}}, \theta_{33}^{(s)}=\frac{\partial Y_{3, t+s}}{\partial u_{3, t}}$

For example, $\theta_{31}^{(s)}$ represents the impact of the pulse $u_{1, t}$ occurring at time $t$ on $Y_{3, t+s}$ at time $t+s$. Equation (7) is the impulse response function. However, the impulse response function only gives a single conclusion for the entire sample interval and cannot capture the specific response between variables at each time point in the sample interval. To do this, we first select a certain point in the sample interval and then accumulate all the pulse effects generated by the fluctuation of a certain variable before the point, that is, the cumulative effect of such pulses on this endogenous variable at that point in time, and this is the point decomposition algorithm of the fluctuating factor, $e_{t}$ in Eq. (8). This algorithm implements the measurement of the fluctuation of the variable at a specific time point and effectively utilizes the sample information.

$e_{1}=\theta_{31}^{(1)} u_{1,1}$,

$e_{2}=\theta_{31}^{(2)} u_{1,1}+\theta_{31}^{(1)} u_{1,2}$,

$e_{3}=\theta_{31}^{(3)} u_{1,1}+\theta_{31}^{(2)} u_{1,2}+\theta_{31}^{(1)} u_{1,3}$.

\subsection{Data sources and data processing}

At the supply level, global crude oil supply can reflect crude oil production in the major crude oil producing areas under the current geopolitical situation, as well as certain technical levels and mining plans. The North Sea oil field is a world-famous oil producing area, and its output includes the sum of crude oil production in five countries including Britain, Norway, Germany, the Netherlands, and Denmark. Cushing is located in Penn County, north-central Oklahoma, USA, where there are many intersecting pipelines and storage facilities, and the physical facilities are an important hub, so its inventory is a key variable in this analysis. At the demand level, because crude oil is indispensable in modern industry, the actual demand for global crude oil is closely related to the state of the world economy, reflecting the level of vitality of the real economy. The demand indicators in this paper are expressed in the international dry bulk oneway maritime price index, which is known as the "Kilian Index". At the speculative level, futures prices in the world crude oil market are composed of two indicators: WTI and Brent. There are arbitrage opportunities existing in crude oil futures price of New York Mercantile Exchange and the London Intercontinental Exchange because they are 4000 miles apart. It is easy to form speculative demand, which is the main factor for futures price fluctuations.

World crude oil supply, WTI futures prices, and Cushing crude oil inventories are all from official EIA statistics, and Brent futures prices are quoted from the CEIC Web site. The US CPI index comes from the Federal Reserve's online economic data database. Given that the significant separation period between WTI and Brent futures prices is from 2011 to 2015, the sample interval is selected from November 2010 to November 2018. In order to capture the dynamic 
Table 2 Unit root test

\begin{tabular}{lll}
\hline Variable name & ADF test & PP test \\
\hline worldsup $_{t}$ & $-8.8043^{* * *}$ & $-10.1788^{* * *}$ \\
& $(0.0000)$ & $(0.0000)$ \\
brentsup $_{t}$ & $-10.1647 * * *$ & $-12.6405^{* * *}$ \\
& $(0.0000)$ & $(0.0001)$ \\
cushingst $_{t}$ & $-5.2906^{* * *}$ & $-5.1449 * * *$ \\
& $(0.0000)$ & $(0.0000)$ \\
oildm $_{t}$ & $-3.0060^{* *}$ & $-3.1860^{* *}$ \\
& $(0.0379)$ & $(0.0239)$ \\
brentfutpr $_{t}$ & $-6.9171^{* * *}$ & $-6.6418^{* * *}$ \\
& $(0.0000)$ & $(0.0000)$ \\
wifutpr $_{t}$ & $-6.9893 * * *$ & $-6.6968^{* * *}$ \\
& $(0.0000)$ & $(0.0000)$ \\
\hline
\end{tabular}

The data values in parentheses are $P$ values, **, and *** indicate the statistical significance at levels of $5 \%$ and $1 \%$, respectively

characteristics of the international crude oil market in more detail, all data are monthly frequencies.

For the comparability of the results, we convert the nominal price of crude oil futures into the real price, that is, the price of the crude oil futures dollar is reduced by the US CPI index, and the pulses are all treated in the same way. In addition, in view of the stability requirements of the SVAR model for data, we perform a stationarity test on the original sequence. Considering the possible heteroscedasticity of time series data, this paper uses both ADF (Augmented Dickey-Fuller Unit root Test) and PP (Phillips-Person Unit root Test). The results show that each variable undergoes seasonal adjustment, logarithm, and first-order difference, which are stationary time series (see Table 2).

\subsection{Restrictions}

The SVAR model is characterized by combining shortterm economic constraints with Cholesky decomposition in mathematics to achieve parameter estimation. There are nine parameters in the structure matrix $D_{0}$ in Eq. (1). Since the covariance matrix is a symmetric matrix, only three short-term constraints are needed to estimate it. Because of the adjustment costs, even if crude oil prices and economic activities fluctuate within a month, companies will not easily change their established production plans, that is, the world's crude oil production is exogenous to the global economic system in the short term. So, in matrix $D_{0}, d_{12}=d_{13}=0$. Further, as developed countries like Europe and the USA use crude oil as their main source of energy, but crude oil is concentrated in the Middle East and North Africa, it takes a certain amount of time for crude oil to be transported from the place of origin to the crude oil-importing country. Therefore, it is also believed that within 1 month, changes in international oil prices will not immediately affect global economic activity, so $d_{23}=0$.

\section{Analysis of empirical results}

Figures 3, 4, 5, 6, 7 and 8 depict the main results of this paper, combined with the supply shock, demand shock, speculative impacts of different models, monthly measurements, and comparative analysis for each model.

Figure 3 shows the effect of the world crude oil supply factors on the Brent and WTI crude oil futures price indicators in Model 1 and Model 2. The most important finding from the chart is that even though Brent and WTI crude oil futures prices have significantly deviated from 2011 to 2015 , the world crude oil supply still has almost the same impact on the two oil price index systems. This indicates that the crude oil futures trading between the London Intercontinental Exchange and the New York Mercantile Exchange is still affected by the fundamentals of the global crude oil market, or that global crude oil supply changes can be ruled out as the reasons for the widening of the spread between the two. In addition, from this chart, it can be seen that the international oil price decline, which started in June 2014, has obvious supply factors, and the effect continues until

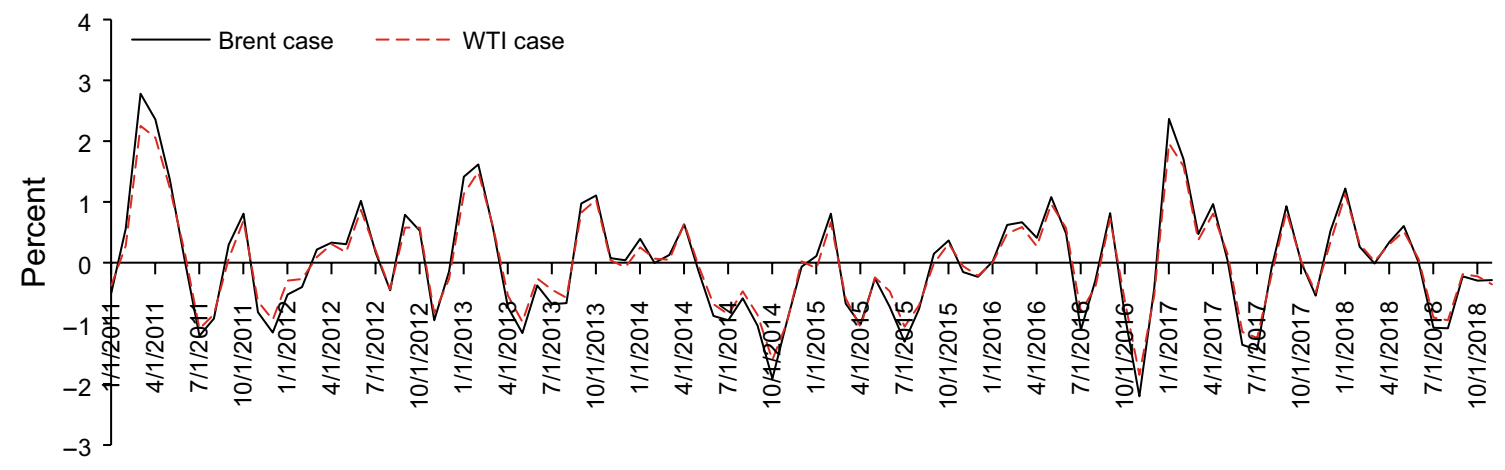

Fig. 3 Effect of world crude oil supply on Brent and WTI futures prices 


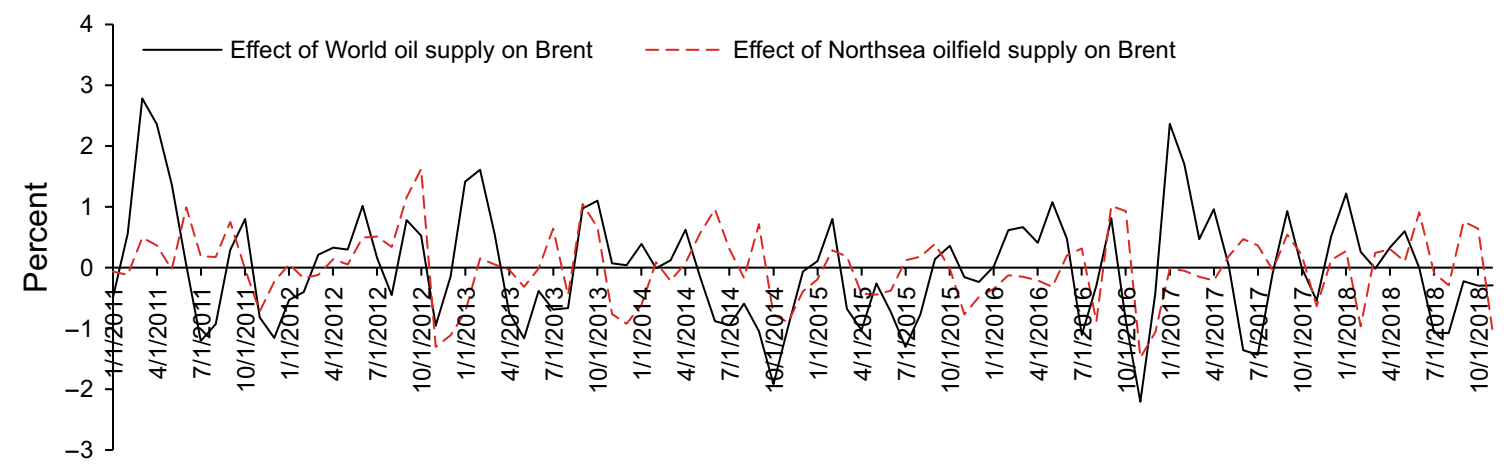

Fig. 4 Influence of supply factors of North Sea oil field and world supply factors on Brent futures prices

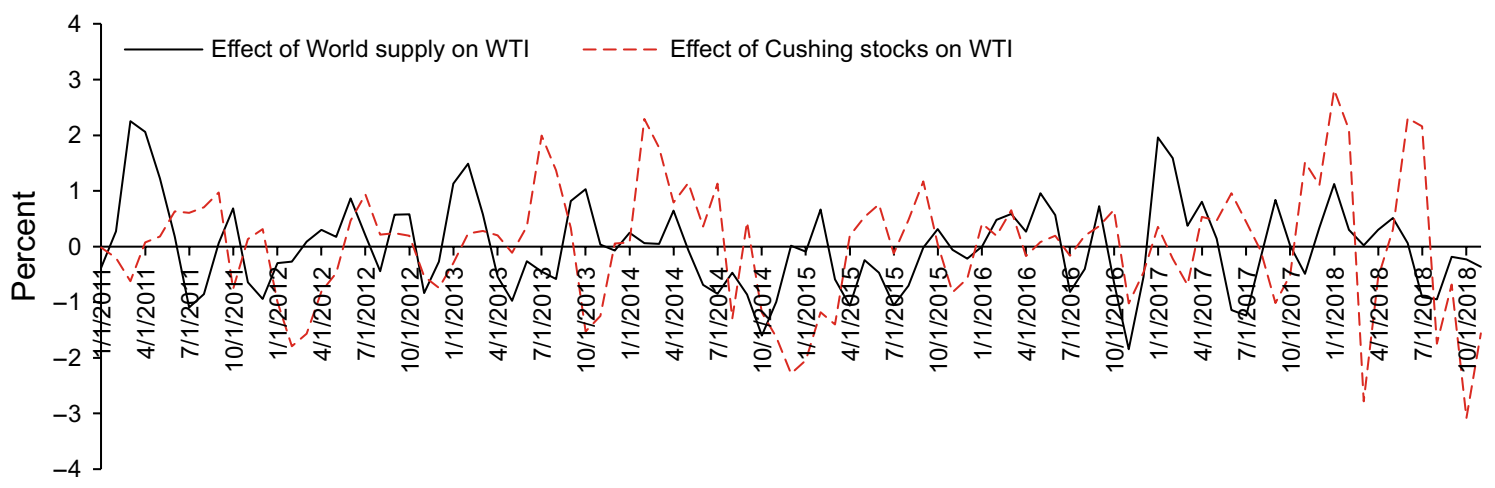

Fig. 5 Impact of Cushing supply and world supply factors on WTI futures prices

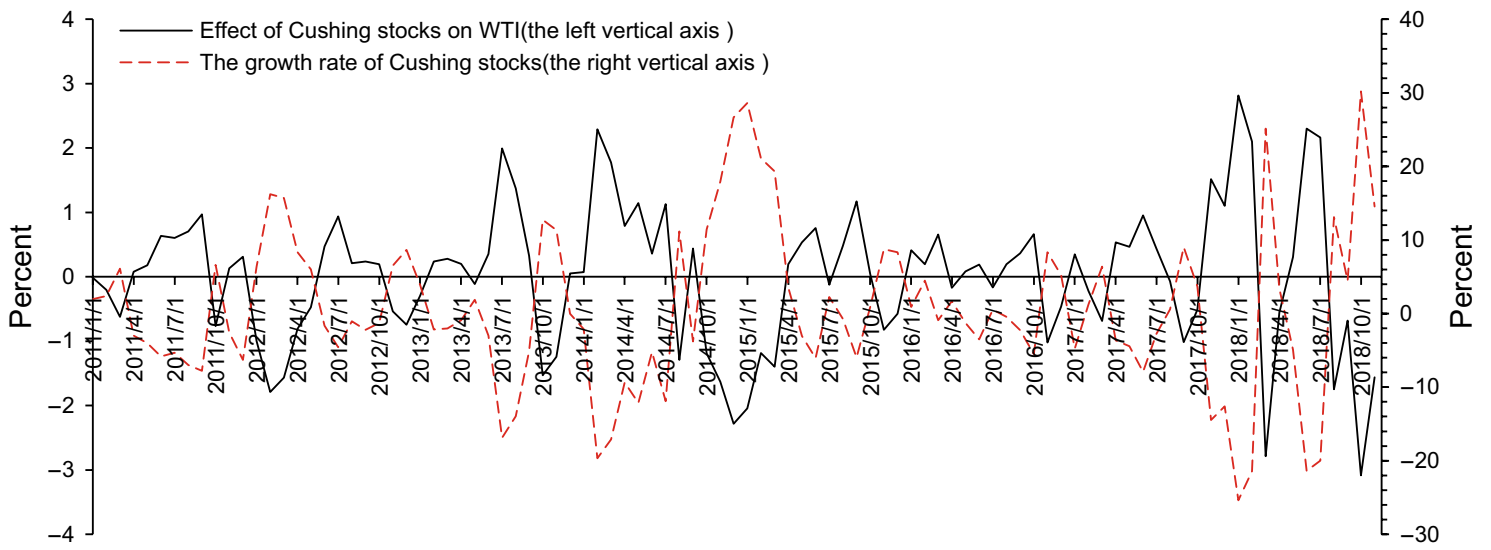

Fig. 6 Cushing's inventory growth rate and the effect of Cushing's inventory on WTI price indicators

January 2015. Figure 3 shows that the rapid rebound in oil prices at the end of 2016 was due to the agreement between OPEC countries and Russia on November 30 of the same year that daily output would be reduced by 1.8 million barrels compared to October. This quickly increased oil prices in the short term. It can be seen that the monthly analysis of the point decomposition of the fluctuating factors realizes the microscopic observation that the previous measurement methods cannot achieve.

Since the global supply of crude oil has not affected the phased separation of Brent and WTI prices, this article goes into the specifics of the market in which each futures price is established. Figures 4 and 5, respectively, show the impact of crude oil production in the North Sea oil field on Brent 


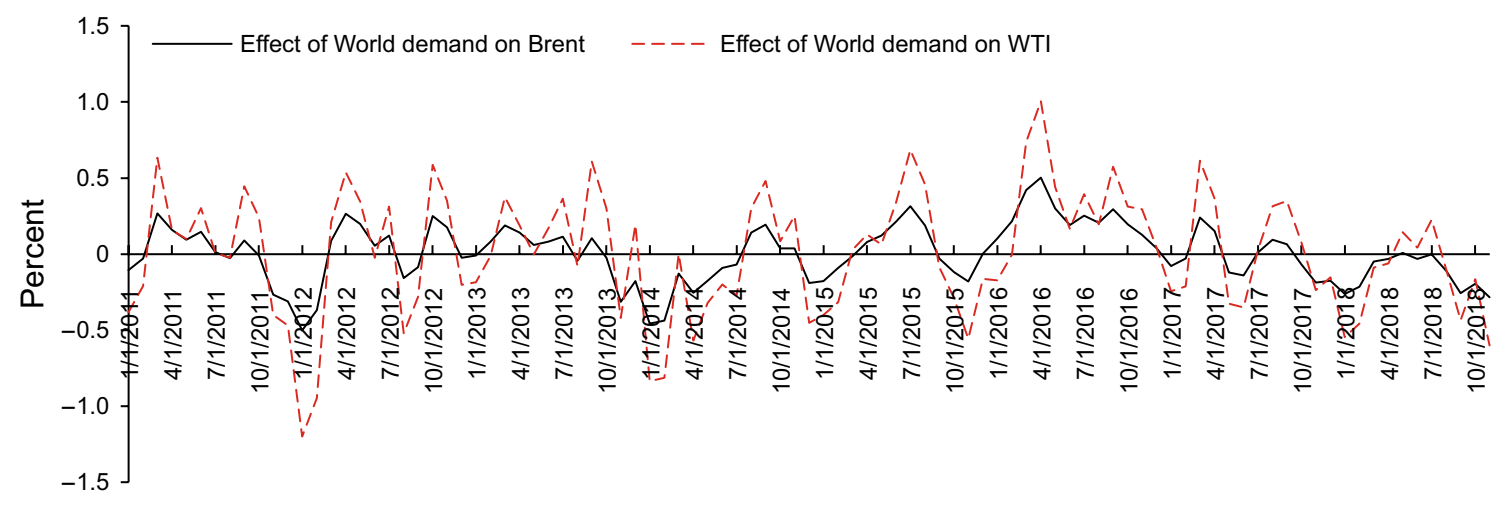

Fig. 7 Impact of world demand factors on Brent and WTI futures prices

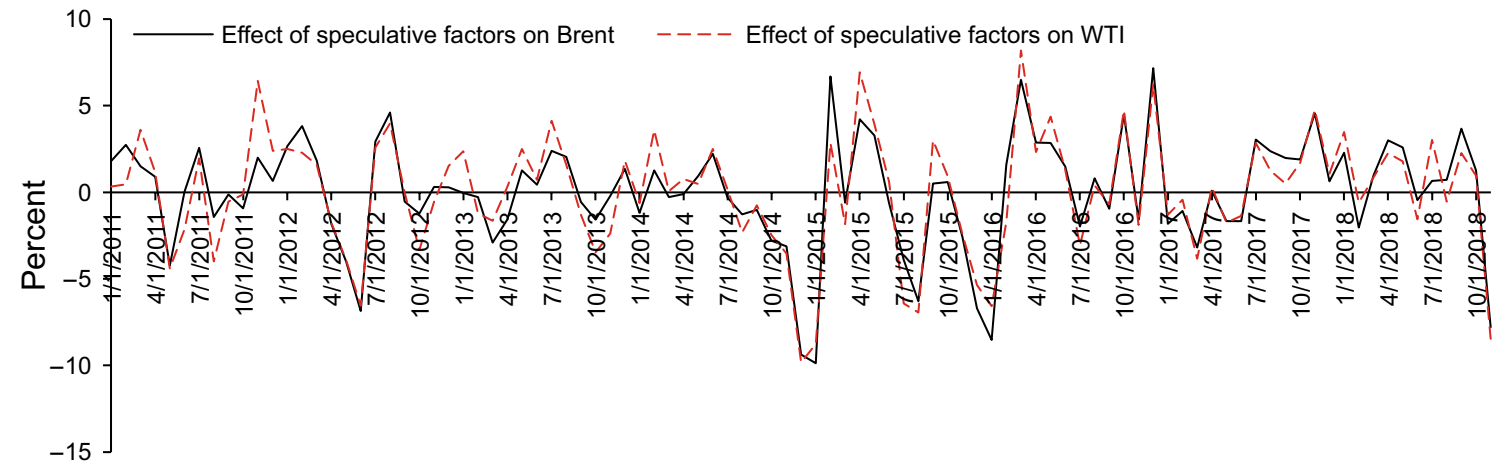

Fig. 8 Impact of speculative factors on Brent and WTI futures prices

crude oil futures prices and the impact of Cushing stocks on WTI crude oil futures prices, with a view to discover the root causes of fluctuations between them.

Figure 4 depicts the changes in the Brent crude oil futures price indicators in Model 1 and Model 3 when they are impacted by the world crude oil supply shock or the North Sea crude oil supply. The figure shows that the Brent futures price index is significantly more affected by the world crude oil supply than the North Sea oil field. The reasons are as follows: (1) The crude oil production in the North Sea oil field has declined faster than expected, mainly due to the aging of the oilfield and the increase in production costs (see Fig. 2). Data from the Chicago Mercantile Exchange showed that production fell $38 \%$ between 2010 and 2013, and daily oil production fell by 500 million barrels. The depletion of the North Sea oil field has led to a significant decline in the amount of crude oil extracted, and its influence on the London futures market has been greatly weakened. (2) Although the scale of local crude oil production has become smaller, the trading volume on the London Intercontinental Exchange accounts for more than half of the world's crude oil futures trading volume. Therefore, the reference indicators for futures market traders are still based on the overall situation in the world crude oil market. (3) Because Europe is connected to the Middle East and Asia on the mainland, the geopolitical situation in the Middle East and Europe, and the actual consumption needs of Asian countries such as China and Japan have a direct impact on the oil price in the London futures market. Therefore, the Brent futures price index system still reflects the real-time fluctuations of the world crude oil market. In addition, Fig. 4 shows the main reason why the Brent oil price is higher than the WTI oil price during the period from June to November 2014: The effect of the supply factor of the North Sea oil field is greater than the effect of the world supply factor, actually raising the Brent oil price index, so objectively the spreads between Brent and WTI have been expanded. During this period, the world's crude oil supply was in surplus, and the North Sea oil field still passed on the information of the crude oil depletion to the traders in the intercontinental exchange market, thus raising the price of the Brent futures contracts.

Contrary to the conclusions derived from the Brent indicators in Figs. 4 and 5, using the supply factors of Model 2 and Model 4 shows that the influence of Cushing crude oil inventories on WTI crude oil futures prices is greater than the impact of world crude oil supply for most of the 
periods since 2012. From July 2013 to June 2014, and from February 2017 to November 2018, the impact of Cushing's inventory on WTI futures price indicators is opposite to the impact of the world crude oil supply on WTI futures price indicators. This became the main force for the narrowing of the WTI and Buren's spread during this period. In February 2012, October 2013, and December 2014, Cushing crude oil inventories drastically reduced the WTI futures price and expanded the spread between them, and it became an important evidence of the stage difference between them. Only in 2016 is the effectiveness of the two on WTI basically the same. In terms of impact timelines, the role of Cushing's inventory lags behind the immediate effect of the world crude oil supply, showing the regional characteristics of Cushing crude oil inventories. That is to say, after the fundamentals of the world crude oil market begin to change, they are transmitted to the domestic production and transportation of crude oil. It can be seen that the WTI crude oil futures price index is very sensitive to the changes in the domestic crude oil market supply and inventory, making the WTI price system more suitable for expressing the regional crude oil futures price index in the USA.

Figure 6 shows the comparison of the effect of Cushing crude oil inventories on WTI with the actual growth rate of Cushing's inventories in order to further study the dynamics of WTI prices and determine the source of their fluctuations. It can be found that they are similar in the opposite direction, that is, Cushing's inventory increases, driving down WTI futures prices; Cushing's inventory decreased and WTI futures prices have gone up. Since 2011, their relationship has been close with each other. The specific performance is that Cushing's inventory is seriously backlogged, while WTI prices are significantly lower than Brent's. Referring to Fig. 1, in November 2012, November 2013, and December 2014 , the WTI index per barrel of oil was lower than the Brent index by $\$ 22.79, \$ 13.97$, and $\$ 3.97$, respectively. In the same period, Cushing's inventory increased by $6.53 \%$, $11.35 \%$, and $26.65 \%$, respectively, and the inventory back$\log$ increased. Therefore, the WTI price system shows the dynamic characteristics of the US domestic crude oil market, and its representation in the world crude oil market has gradually weakened.

At the supply level, we discuss the world crude oil supply, the North Sea crude oil production, and the Cushing crude oil stocks, respectively, and the impact of the actual consumption demand for world crude oil which is closely related to the world economic vitality of the WTI and Brent indicator systems. According to the impact response of the demand factors in Model 1 and Model 2, Fig. 7 shows the consistency of the time trend and the difference in the influence range. First of all, among the many reasons for the sharp drop in international oil prices in 2014 was the reduction in demand for crude oil caused by the sluggish world economy. In the first half of 2016, the rebound in oil prices also reflected the rise of the world economy after the bottoming out in 2015. The vitality of the world economy has simultaneously acted on the two major trading indicators of the world crude oil futures market, causing both to change at the same time. Second, the biggest finding from Fig. 7 is that the WTI indicator system is more responsive to the needs of the world's real economy than the Brent indicator system. The conclusion is that although the WTI indicator reflects the domestic crude oil market at the supply level, it also reflects the dynamics of the world economy at the demand level. It can be seen that the status of the USA as the center of the world economy has not changed, and it can reflect the changes in the world economic climate in a timely manner. It is worth noting that in January 2012 and January-February 2014, the world demand factor suppressed the WTI index by several times the Brent index, which also caused the WTI price to be lower than the Brent price. In the recovery of the world economy in 2016, WTI was more active than Brent, because the acceleration of the US economic recovery was significantly faster than that of European countries.

The results shown in Fig. 8 were calculated using the arbitrage speculative demand factors in Model 1 and Model 2. Figure 8 shows that when the Brent crude oil futures price index is higher than the WTI index between 2011 and 2015, the trader uses the spread of the two to carry out arbitrage activities: The speculative factors for arbitrage tend to focus on the WTI futures price, using its low price to carry out the buying operation, which is to a certain extent greater than the increase in the price of Brent. It is worth noting that on December 18, 2015, the USA lifted the 40-year crude oil export ban, eliminating the situation whereby the US domestic crude oil surplus cannot be exported, and the WTI index is low, which is likely to cause arbitrage. At the same time, the transportation pipeline between Cushing and the Gulf of Mexico was newly built, and the daily output of crude oil increased by more than 1 million barrels. This reconnects WTI with international crude oil prices, WTI, and Buren's spread, greatly reducing speculative activities and the effect curves of the two are almost coincident (see the situation after 2015 in Fig. 8).

\section{Conclusion}

The world's crude oil market is still the biggest variable in global economic development. In the long-term development of the world crude oil futures market, the two price index systems of WTI and Brent have developed, and the spreads have been maintained in the normal range of about $\$ 2 /$ barrel for a long time. However, during the period between 2011 and 2015, there was a phased separation between the two, and at the end of 2012, there was an 
extreme spread of $\$ 24$, which caused great concern in the economic community. In this context, this paper uses the time-point decomposition method of fluctuating factors to construct a dynamic multi-model comparative analysis framework. From the basic supply and demand side of the world crude oil market, we analyze the world crude oil supply, the crude oil supply of the North Sea oil field, the US Cushing crude oil inventory, the increase in US shale oil production, the lifting of the US crude oil export ban, actual world crude oil consumption demand and speculative demand, and other factors in examining their specific role in the spread between them. The study found:

At the first level, the reasons for the WTI and Brent spread between 2011 and 2015 were supply-level factors: January 2011-April 2011, April 2012-April 2013, December 2012-April 2013, and January-March 2015, world crude oil supply increased Brent oil prices; January 2012-April 2012, August 2013-December 2013, and July 2014-2015, Cushing's inventory factor significantly lowered WTI oil prices, causing the spread between the two to widen; Demand level factors: During the period from 2011 to 2015 , when the world economy was sluggish, the actual consumption demand for crude oil and the pressure on oil prices caused the WTI price index to fall more than the Brent index, resulting in a more dramatic decline in WTI prices and making it much lower than the Brent indicator system. Regarding the speculative factors, because WTI is subject to the Cushing stock, its price is lower than Brent oil prices, so futures market traders are more likely to carry out arbitrage trading on the New York Commercial Futures Exchange. However, due to the impact of the US crude oil export ban before 2015, the increase was small. Only after the crude oil export ban was lifted was the US crude oil export unimpeded.

On the second level, the current Brent crude oil futures price index can better reflect fluctuations in the supply level of the world crude oil market, and WTI can better reflect fluctuations in the demand level of the world crude oil market. However, both have their own problems: For example, the depletion of the North Sea oil field has led to a rapid decline in its production, which may affect the world influence of the Brent index on the crude oil futures market in the future; after the US shale oil production increased, due to the limited domestic transportation capacity, the changes in Cushing's inventory significantly affected the changes in the WTI price index system, making it more reflective of changes in the US domestic market. In the future, the world crude oil market futures price index needs to have a new futures market with stable production, wide trading varieties, and huge trading volume at its trading location.

The useful revelations of this article are:

First, the developed futures market is a favorable condition for the international price index of crude oil owned by the New York Mercantile Exchange and the London Intercontinental Exchange. However, from the conclusion of this paper, it can be seen that many factors such as crude oil production, transportation capacity, and policy regulations in the country where the futures market is located can also affect the strength of this indicator in the world crude oil market. Therefore, while actively developing a crude oil futures market, China should stabilize domestic production and expand overseas oil sources to fundamentally maintain China's position in the world crude oil market.

Second, the existing system of WTI and Brent crude oil futures prices representing the world benchmark indicators has been challenged, so the Chinese crude oil futures market should rely on China's huge crude oil demand and crude oil trade to improve various aspects of system construction, database construction, trading platform construction, and domestic crude oil market structure construction. Then, this market could strive to become a crude oil futures trading market with world influence, or at least with influence in the Asia-Pacific region, so that Shanghai crude oil futures prices will become an important representative indicator in the world crude oil futures market, ultimately fighting for the right to speak for and serve China's economic development.

Open Access This article is distributed under the terms of the Creative Commons Attribution 4.0 International License (http://creativeco mmons.org/licenses/by/4.0/), which permits unrestricted use, distribution, and reproduction in any medium, provided you give appropriate credit to the original author(s) and the source, provide a link to the Creative Commons license, and indicate if changes were made.

\section{References}

Adelman MA. International oil agreements. Energy J. 1984;5(3):1-9. https://doi.org/10.5547/ISSN0195-6574-EJ-Vol5-No3-1.

Alquist R, Kilian L. What do we learn from the price of crude oil futures? J Appl Econom. 2010;25(4):539-73. https://doi. org/10.1002/jae.1159.

Alquist R, Guénette JD. A blessing in disguise: the implications of high global oil prices for the North American market. Energy Policy. 2014;6:49-57. https://doi.org/10.1016/j.enpol.2013.07.002.

Aloui R, Ben Aïssa MS, Nguyen DK. Conditional dependence structure between oil prices and exchange rates: a copula-GARCH approach. J Int Money Finance. 2013;32(2):719-38. https://doi. org/10.1016/j.jimonfin.2012.06.006.

Baumeister C, Kilian L. Real-time analysis of oil price risks using forecast scenarios. IMF Econ Rev. 2014;62(1):119-45. https:// doi.org/10.1057/imfer.2014.1.

Bedoui R, Braiek S, Guesmi K, et al. On the conditional dependence structure between oil, gold and USD exchange rates: nested Copula based GJR-GARCH model. Energy Econ. 2019. https://doi. org/10.1016/j.eneco.2019.02.002.

Brennan MJ. The supply of storage. Am Econ Rev. 1958;48(1):50-72. https://doi.org/10.1007/978-1-349-02693-7_5.

Büyüksahin B, Lee TK, Moser JT. Physical markets, paper markets and the WTI-Brent spread. Energy J. 2013;34(3):129-51. https://doi. org/10.5547/01956574.34.3.7. 
Carter CA, Smith A. Estimating the market effect of a food scare: the case of genetically modified starlink corn. Rev Econ Stat. 2007;89(3):522-33. https://doi.org/10.1162/rest.89.3.522.

Chen W, Huang Z, Yi Y. Is there a structural change in the persistence of WTI-Brent oil price spreads in the post-2010 period? Econ Model. 2015;50(11):64-71. https://doi.org/10.1016/j-econm od.2015.06.007.

Chu W-T, Xu Z-H. Causes and influence of the WTI-Brent spread anomaly. Int Pet Econ. 2011;19(9):7-14. https://doi.org/10.3969/jissn.1004-7298.2011.09.002 (in Chinese).

Fattouh B. The dynamics of crude oil price differentials. Energy Econ. 2010;32(2):334-42. https://doi.org/10.1016/j-eneco.2009.06.007.

Ghoshray A, Trifonova T. Dynamic adjustment of crude oil price spreads. Energy J. 2014;35(1):119-36. https://doi. org/10.5547/01956574.35.1.7.

Han L-Y, Zhen Z, Cai L-X. Long and short term impacts to global oil prices. Chin J Manag Sci. 2017;25(8):68-78. https://doi. org/10.16381/j.cnki.issn1003-207x.2017.08.008 (in Chinese).

Heidorn T, Mokinski F, Ruhl C, et al. The impact of fundamental and financial traders on the term structure of oil. Energy Econ. 2015;48:276-87. https://doi.org/10.1016/j.eneco.2015.01.001.

Ji Q, Fan Y. Evolution of the world crude oil market integration: a graph theory analysis. Energy Econ. 2016;53(1):90-100. https:// doi.org/10.1016/j.eneco.2014.12.003.

Kao C-W, Wan J-Y. Price discount, inventories and the distortion of WTI benchmark. Energy Econ. 2012;34(1):117-24. https://doi. org/10.1016/j.eneco.2011.03.004.

Kilian L. Not all oil price shocks are alike: disentangling demand and supply shocks in the crude oil market. Am Econ Rev. 2007;99(3):1053-69. https://doi.org/10.1257/aer.99.3.1053.

Kilian L. The impact of the shale oil revolution on US oil and gasoline prices. Rev Environ Econ Policy. 2016;10(2):185-205. https://doi. org/10.1093/reep/rew001.

Kilian L, Murphy DP. The role of inventories and speculative trading in the global market for crude oil. J Appl Econom. 2014;29(3):45478. https://doi.org/10.1002/jae.2322.

Kolodziej M, Kaufmann RK. The role of trader positions in spot and futures prices for WTI. Energy Econ. 2013;40(2):176-82. https ://doi.org/10.1016/j-eneco.2013.06.002.

Liu W-M, Schultz E, Swieringa J. Price dynamics in global crude oil markets. J Futures Mark. 2015;35(2):148-62. https://doi. org/10.1002/fut. 21658.

Liu P, Stevens RB, Vedenov D. The physical market and the WTI/Brent price spread. OPEC Energy Rev. 2018;42(1):55-73. https://doi. org/10.1111/opec.12117.

Makki SS, Tweeten LG, Miranda MJ. Wheat storage and trade in an efficient global market. Am J Agric Econ. 1996;78(4):879-90. https://doi.org/10.2307/1243845.

Miranda MJ, Glauber JW. Solving stochastic models of competitive storage and trade by chebychev collocation methods. Agric Resour
Econ Rev. 1995;24(1):70-7. https://doi.org/10.1017/S106828050 0003622.

Redl C. Noisy news and exchange rates: a SVAR approach. J Int Money Finance. 2015;58(11):150-71. https://doi.org/10.1016/j.jimon fin.2015.08.002.

Scheitrum DP, Carter CA, Revoredo-Giha C. WTI and Brent futures pricing structure. Energy Econ. 2018;72:462-9. https://doi. org/10.1016/j.eneco.2018.04.039.

Shi X-P, Ji Q, Zhang D-Y. Evolution of international crude oil pricing mechanism and its implications to China's crude oil futures. J Environ Econ. 2018;3(3):127-40. https://doi.org/10.19511/j.cnki. jee.2018.03.009 (in Chinese).

Sui Y-X, Guo Q. The impact of speculation factors in futures markets on international oil price fluctuations-based on structural breakpoint analysis from 2000 to 2013. Macroeconomics. 2014;8:10013. https://doi.org/10.16304/j.cnki.11-3952/f.2014.08.013 (in Chinese).

Tian H-Z. Did economic growth of China affect international prices of oil? World Econ Stud. 2015;10:80-9. https://doi.org/10.13516 /j.cnki.wes.2015.10.009 (in Chinese).

Wang Q-Z, Wang Y-D. International transmission of volatility among crude oil prices, economic uncertainty and the stock market. Chin J Manag Sci. 2018;26(11):50-61. https://doi.org/10.16381/j.cnki. issn1003-207x.2018.11.006 (in Chinese).

Weiner RJ. Is the world oil market "One Great Pool"? Energy J. 1991;12(3):95-107. https://doi.org/10.5547/ISSN0195-6574-EJVol12-No3-7.

Working $\mathrm{H}$. The theory of price of storage. Am Econ Rev. 1949;39(6):1254-62. https://doi.org/10.2307/1232678.

Wright BD, Williams JC. The roles of public and private storage in managing oil import disruptions. Bell J Econ. 1982;13(2):341-53. https://doi.org/10.2307/3003458.

Yang L, Cai X-J, Hamori S. Does the crude oil price influence the exchange rates of oil-importing and oil-exporting countries differently? A wavelet coherence analysis. Int Rev Econ Finance. 2017;49(3):536-47. https://doi.org/10.1016/j.iref.2017.03.015.

Ye S-Y, Karali B. Estimating relative price impact: the case of Brent and WTI. In: 2016 Agricultural \& applied economics association annual meeting, Boston, Massachusetts, July 31-August 2, 2016.

Yu L-A, Zha R, He K-J, et al. The analysis of dependence relationship between oil and stock prices: evidence from China and American industrial sector indices. Chin J Manag Sci. 2018;26(11):74-82. https://doi.org/10.16381/j.cnki.issn1003-207x.2018.11.008 (in Chinese).

Živkov D, Njegić J, Balaban S. Revealing the nexus between oil and exchange rate in the major emerging markets-the timescale analysis. Int J Finance Econ. 2019;24(7):685-97. https://doi. org/10.1002/ijfe.1686. 